\title{
Lessons from Hydropower Rich Paraguay
}

\section{Jeewan P. Thanju, with Ricardo Canese's technical review}

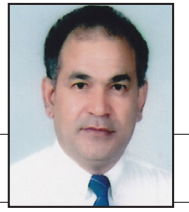

Jeewan P. Thanju

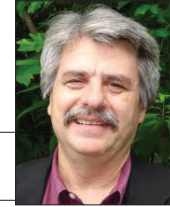

Ricardo Canese

\begin{abstract}
Despite Paraguay being one of the largest net exporters of electricity in the world (for decades and the main electricity exporter in South America accounting for $85 \%$ of all exports), it is the second poorest nation in South America after Bolivia. It is the half owner of the $14,000 \mathrm{MW}$ Itaipu hydro electric complex. Paraguay gets a small fraction of the market price for the exported electricity to Brazil. The Brazilians viewpoint is that the spirit of the treaty is to recover the investment cost and not the commercial price. Hence, there is widespread discontent among the Paraguayans. One Paraguayan minister has commented that it is a real politik of an ant staring at an elephant.
\end{abstract}

Likewise, in Yacyretá, a 3,100MW hydroelectric plant constructed in association with Argentina, Paraguay is not getting a good return. Construction work was stopped for several years by Argentina due to various reasons. Further, planning and feasibility studies were not done in sufficient detail. It is claimed that environmental and ecological considerations were not undertaken in its planning.

Paraguay has not sufficiently benefited from the two huge bi-national hydro power projects. Experience of Paraguay may be good lessons for small but hydropower rich countries such as Nepal. Nepalese Officials dreaming to earn several tens of billions Rupees as export revenue from the half the electricity to be owned by Nepal from the proposed Pancheshwar Dam (6,480MW) need to remember the case of Paraguay.

Key words: Itaipu hydro electric, export price of electricity, Yacyretá Dam, Paraguay

\section{Itaipu Hydro Plant}

The 14,oooMW Itaipu Hydropower Plant had been the largest hydropower station in the world until the completion of Three Gorges $(22,500 \mathrm{MW})$ hydro station in China. In terms of annual power production, however, Itaipu led Three Gorges in 2008 and 2009. The Itaipu plant generates about 92TWh/year, supplies $80 \%$ of the electricity consumed by Paraguay and $19 \%$ of that consumed by Brazil. In 1994, Itaipu Dam was named as one of the seven modern wonders of the world by American Society of Civil Engineers. It is the combined project of Paraguay and Brazil constructed over the border river Parana.

Itaipu Binacional is the owner of the hydro plant, which is jointly administered by Paraguay and Brazil. The treaty signed in April 1973 resulted the Itaipu Power Plant. The financial conditions of the treaty will expire in 2023. ${ }^{1}$ As per the treaty, the excess electricity of Paraguay side is required to be sold to Brazil through its main state owned subsidiary Eletrobas. At the time of the treaty, there were military governments in both Brazil and Paraguay. The project cost was estimated to be US\$2 billion in 1973 but escalated to \$20 billion when completed in 1991.

Paraguay and Brazil are two legally bound equal partners in Itaipu Binacional, having 50\% each of the benefits of the Itaipu even though they are two asymmetrical nations in terms of population and economy size.

Paraguay and Brazil each invested 50 million US dollars initially; the rest coming from loans.

For Itaipu, the main creditor for this debt is Eletrobas, the main state owned (more than 50\%) Brazilian company and main Itaipu Electricity buyer (94\% in 2011). This Itaipu Binacional entity was constituted by ANDE (Paraguay) and ELETROBRAS (Brazil).

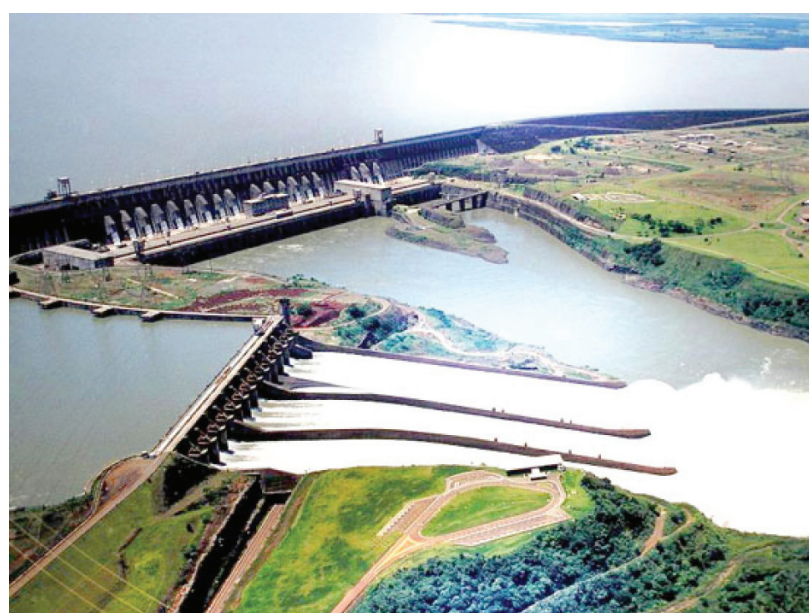

Figure 1. Itaipu Dam

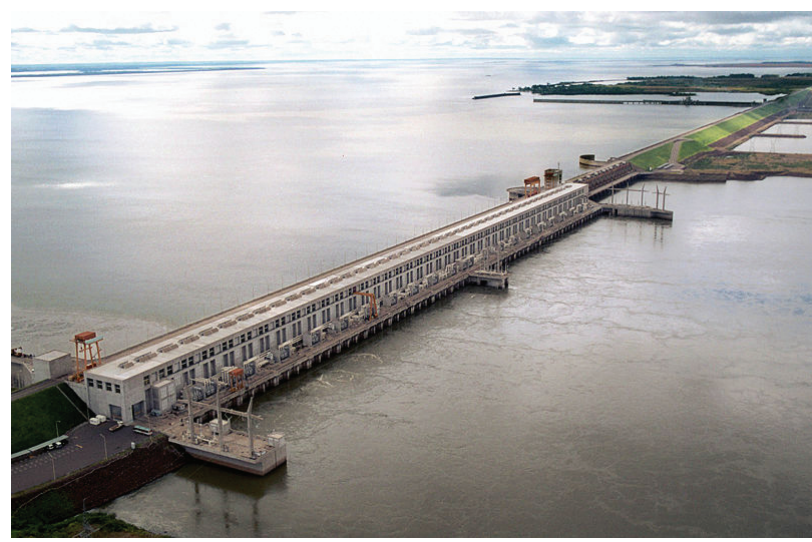

Figure 2. Yacyretá Dam 


\section{Yacyretá Hydro Plant}

Another Hydropower project, Yacyretá, of $3100 \mathrm{MW}$, is located downside of Itaipu and was developed jointly with the Argentine government. It is also not very productive to Paraguayans. It is a low head plant with a head of 22m. Only after decades of plant operation, the project is now operated at designed capacity. There have been substantial cost and time overruns and the investigation and feasibility of the project were not carried out in sufficient detail. Nor were environmental concerns given due importance. Due to submergence of the populated areas, the designed reservoir level of $83 \mathrm{~m}$ was not reached until February 2011. Since 1994 the turbines were running below the rated capacity due to less than designed reservoir water level. The project is criticized for not taking consideration of the ecology and environment during planning and construction. Due to the reservoir created by the dam, a large numbers of species are assumed extinct.

In early 2010 the reservoir level was only 78.5 meters above sea level allowing output of only $65 \%$ of the plant's 3,100MW installed capacity. Yacyretá currently supplies around 14\% of Argentina's electricity consumption.

Both countries invested US $\$ 50$ million each and the rest came as loan. The annual revenue at full production of $\$ 800$ million is not sufficient to service the annual interest of $\$ 950$ million on the huge $\$ 12$ billion debt by 2009 (Nickson 2010). The Argentinean President Carlos Menem characterized Yacyretá as a "monument to corruption" on its huge cost. Due to two decades of construction period (due to several years of work stoppages) and legal aspects, Paraguay argues that much of this debt is 'spurious'. Paraguay is demanding that the debt will be no more than 5 billion dollars and that the rest should be written off. In 2009, Paraguay received $\$ 140$ million from the plant for its share of electricity sold to Argentina.

\section{A Land Locked Country}

The 6.23 million Paraguayans have per capita income of $\$ 1,514$ (2006), whereas the over 190 million Brazilians have per capita income of $\$ 5,660$ (2006). Paraguay's Gross Domestic Product is $\$ 9.11$ billion in year 2006 (Anonymous: nationmaster.com 2011). Paraguay is a land locked country.

Despite owning half the rights to the world's largest hydro station at Itaipu, Paraguay is still the second poorest nation in South America after Bolivia. Agriculture, agribusiness, cattle ranching and electricity export are the main economic activities of Paraguay. The economy has grown due to increased exports of soybeans and beef, and it is the third largest net exporter of electricity in the world.

Paraguay uses electricity for only $15 \%$ of its total energy needs. The per capita electricity consumption per annum is $1,300 \mathrm{kWh}$ (ANDE). More than $90 \%$ of population has access to electricity, but in a very precarious way.

\section{Tariffs}

The revenue/compensation received for the electricity sold to Brazil (from Paraguay's share in Itaipu) and also to Argentina to some extent (from its share in Yacyretá ) is very low. Brazil insists that as per the treaty the price of the exported electricity is based on the recovery of the investment cost plus a non market profit and not the commercial price. The Paraguayan profit for the electricity export to Brazil (compensation) has remained very low. ${ }^{2}$ In 2006, Paraguay earned $\$ 373.6$ million from the Itaipu dam, of which $\$ 196.5$ million was royalties and $\$ 87.3$ million was compensation/profit for energy sold to Brazil's state-run power utilities. The price paid to 
Paraguay was increased in 2005, an additional \$21 million/year payment over the previous year.

Brazil pays only $\$ 2.81 /$ MWh (o.28 US cents per unit (kWh)) compensation (profit) to Paraguay and additionally ELETROBRAS pays $\$ 38 / \mathrm{MWh}$ to Itaipu Binacional. When ELETROBRAS buys the Brazilian electricity from Itaipu, it pays only $\$ 38 / \mathrm{MWh}$ to the binational entity and when it buys the Paraguayan Itaipu energy, it pays $\$ 40.81$ MWh. $^{3}$

Then, the Paraguayan Itaipu electricity is sold by ELETROBRAS to Brazilian market. The Brazilian whole sale electricity market is quite complex. It is important to say that the electricity generation expansion cost in Brazil is about US $\$ 80 / M W h$. In other words, Brazil cannot get an average electricity generation less than US\$ 80/ MWh. Anyway, ELETROBRAS sells the Itaipu electricity to principally state owned distribution companies to a cost basis. So, these companies have a cheap electricity from Itaipu that it is mixed with other quite more expensive electricity from the Brazilian market.

Argentina purchased electricity from Brazil at US $\$ 100 /$ MWh during shortages in 2007 and more in following years. Currently (July, 2011), Argentina is buying electricity from Brazil at $\$ 400 / \mathrm{MWh}$. The average national tariff (2006-2011) in Paraguay was $\$ 0.08$ US per kWh $(\$ 80 / \mathrm{MWh})$, at distribution level.

Only in July 2009, Brazil agreed to pay the triple the amount to $\$ 360$ million (about 8.4 US $\$ / \mathrm{MWh}$ ) compensation up from current about $\$ 120$ million. What Brazil currently pays Paraguay for electricity (in 2011) is quite the same that Paraguay was scheduled to receive from Argentina under the Treaty of Yacyretá (about \$9/ MWh). In 2011, Paraguay and Uruguay made a preagreement about Paraguayan electricity to be exported; and Paraguay will receive about 80 o $/ \mathrm{MWh}$ net profit, nine times what Brazil and Argentina pay as compensation to Paraguay, but the Paraguayan electricity has not yet been sent to Uruguay because Argentina has not agreed to the transmission conditions. If Paraguay can sell its excess electricity (45 million MWh/year) to Chile, Uruguay and Argentina at energy market prices, it would have about $\$ 2$ billion/year net profits, compared to only $\$ 360$ million/year net profit (in compensation) that Brazil is currently paying.

\section{Discontent of Paraguayans}

There is wide discontent in Paraguay regarding the dismal price paid by the Brazil. Paraguay demands market price whereas Brazil reiterates that the spirit of the treaty is to recover the investment. This is a treaty between two neighboring nations who are legally equal but politically and economically unequal. President Fernando Lugo of Paraguay during his election campaign stated that his main agenda was to renegotiate with Brazil to get a fair price for its exported electricity. For a long time, Brazil refused to increase the price of the Paraguayan electricity, nor did it allow the sale of electricity other than through the designated agency.

Despite the legal obligation for 'alternating directorships', ever since the project came on line in the mid-1980s, the finance and technical directorships of the bi-national hydro company, Itaipu Binacional, have remained exclusively in Brazilian hands and the Paraguayan National Audit Office has not been allowed to examine the company accounts (Nickson 2010). Only recently have Paraguayan auditors been allowed to see the accounts for the Itaipu debt.

Brazil clearly has the upper hand in the matter, including a military that regularly practices seizing and locking down the dam, and the expertise and financing required to run the dam (Stratfor 2009). Jorge Lara Castro, Deputy Foreign Minister of Paraguay, has summed up the issue as this: "At stake is the viability of a poor country... the real politick of an ant staring up at an elephant" (Pun 2010).

President Lugo of Paraguay had been trying to get better price for the exported electricity. In August 2008 (when he began his presidential period), he presented six points to Brazil, as follows :

1. Freedom over use of energy - the ability to sell whatever market it chooses at the price it chooses,

2. A fair price for the energy exported to Brazil,

3. Re-examining the debt incurred during construction of the dam,

4. Equal administration of Itaipu Binacional,

5. Allowing Paraguayan auditors access to audit the account books of Itaipu, and

6. Completion of the pending projects that were stipulated at the treaty.

In January 2009 Brazil offered to pay about $\$ 200$ million per year for the electricity from Paraguay, as well as contribute financing to allow Brazilian companies to build a new electricity transmission line from Itaipu to the Paraguayan capital of Asuncion. The offer was rejected by Paraguay.

After a long persuasion and threat by the Paraguayan to take the case to the International Court of Justice, Brazil agreed only in July 2009 as follows:

1. To pay the triple the amount to US\$360 million annually for the exported electricity up from about $\$ 120$ million.

2. Brazil will "consider" the future possibility to sell electricity to third countries together with Paraguay, after 2023.

3. Brazil agreed that Paraguay can concede a "gradual direct sale of energy to the Brazilian market" (MercoPress 2009). (Paraguay presented a formal proposi- 
tion to sell Paraguayan Itaipu electricity to the Brazilian market in June 2010, but as of June 2011 Brazil had not yet replied.)

4. Brazil will finance a non reimbursable loan to allow Itaipu Binacional to construct a $35 \mathrm{okm}$ long $500 \mathrm{kV}$ transmission line costing US $\$ 45^{\circ}$ million to take power to the capital of Paraguay.

5. Paraguay and Brazil will govern Itaipu Binacional together (under a co-administration agreement).

6. The Paraguayan Comptroller General (Contraloría General de la República) will audit (review) all the Itaipu debt. (Currently it is under study.)

Paraguay's main Itaipu demands for fair price, free disposal of surplus power and review of the overall debt was an important advancement as of July 2009, 36 years after Itaipu Treaty was signed. But it is not yet a complete achievement. Many believe the personal chemistry of President Lugo and President Silva is responsible for the new deal. Both the presidents have background of same church affiliation.

There is US $\$ 16.5$ billion debt (at end of 2010) owed on Itaipu, half of which is on Paraguay's account. Paraguay claims that this debt is illegal, as the amount is much higher than originally agreed upon in the treaty.

Paraguay lacks infrastructures like sufficient transmission lines to dispatch electricity in the various parts of the country. Further, it has not been able to attract foreign direct investment to open energy-hungry industries in the country. Only in January 2009, President Lugo signed a decree introducing special tariff rates for energy-intensive industries. Rio Tinto Alcan, an aluminum industry giant, intends to invest in Paraguay, but there is no tariff agreement yet. The Paraguayan government says that the investment is welcome if there is not an under cost electricity tariff needed. The proposed industry will cost US $\$ 2.5$ billion and will consume $800 \mathrm{MW}$ of power.

Paraguay needs to initiate the consumption of a large amount of electricity inside the country by establishing industries, laying lines of electrically run railways, trolley buses or electrical battery operated vehicles, to consume large amounts of electricity.

\section{Brazilian View Point}

Brazilians are unhappy being portrayed as profiteers. The Brazilian government provided the collateral for the loan to Paraguay, but Brazilians believe that their financial and technical contributions have been forgotten.

Itaipu supplies about $19 \%$ of the electricity to Brazil; hence, it has high strategic importance to Brazil. The inequitable arrangement of Itaipu is of enormous economic advantage to Brazil. Brazil is emerging as a geopolitical power in South America and intends to put its point of view in global matters.

\section{Lessons for Nepal or a Small country}

Many people in Nepal, especially at the policy level, see Nepal becoming rich by exporting electricity. Further, Nepal's politicians are mesmerized by the benefits of electricity export from half share of the proposed 6,48oMW Pancheshwar High Dam along the border river between India and Nepal. Nepal is entitled to half of the electricity generated. Pashupati S.J.B. Rana, when he was Water Resources Minister of Nepal, declared that the sun will rise from the west once the Pancheshwar Dam is commissioned. Several political leaders estimated that the annual income for Nepal from the electricity export sales from the Pancheshwar Dam will be Rs.21 billion to 120 billion (US $\$ 0.293$ billion to $\$ 1.678$ billion). D.B. Singh, Nepal's Pancheshawer Project Chief, came up with a figure of Rs.45.88 billion Rupees (US\$0.64 billion) annual revenue from the project. Paraguayan experiences may be good lessons for Nepal: instead of exports, in country self consumption is a better idea.

The export of about 38 million MWh of electricity annually of Paraguay from Itaipu is similar to the Nepal's proposed 10,800MW Karnali project, half share of the proposed 6,480MW Pancheshawer, and the proposed 3,oooMW Koshi project. Based on the scenario and lessons from Paraguay, it is necessary that Nepal be vigilant in future deals with India. Most Nepalese believe that it has a history of not getting a fair deal with India in its treaties/agreement in water resources projects on the rivers Koshi, Gandak and Mahakali. In the present situation, the government of India has designated the Power Trading Corporation of India as the single nodal agency through which all Nepal-India power transactions need to be routed.

S.B. Pun, in a 2010 article in HYDRO Nepal stated that Paraguay landed in the proverbial frying pan for the exported electricity. Pun cautions that Nepal may also land in the same frying pan as the Paraguayan did, unless the Nepalese understand the intricacies of the treaty and negotiations. For this, Nepal needs to strengthen its institutions to be capable of negotiating for a fair share of benefits.

\section{Conclusion}

The 14,00oMW Itaipu Hydroelectric Complex is a technically and financially successful project producing cheap and reliable electric power. However, as the half owner of Itaipu, the revenues (profits) received by Paraguay from the sale of electricity to Brazil are dismal compared to market prices. Paraguay has failed hopelessly to get a fair price for the exported electricity. The terms of the treaty with Brazil are not favorable to Paraguay. Furthermore, the agreed terms are not implemented and Brazil retains the upper hand. It is a sense of the "real politik of an ant staring at an elephant" as visualized by a Paraguayan minister. Only 36 years after the Itaipu Treaty was signed, were improvements incorporated in 
the treaty terms. Since 2011, Paraguay will receive three times more revenue than in the past for its electricity export to Brazil; but it is not yet at market price.

Further, Paraguay is not getting reasonable benefit from the Yacyretá (310oMW) Hydro Electric Plant, which was constructed jointly with neighboring Argentina. There were massive time and cost overruns in the two decades of construction period. This project has also been criticized for not taking environmental and ecological considerations.

The following are the lessons from Paraguay:

1. Paraguay needs to learn a lesson to consume electricity as much as possible in energy hungry industries, homes, transportation, etc., instead of exports. Further, a treaty/agreement needs to include a clause for a freedom to export surplus electricity.

2. A small country needs to be careful in drafting treaties/agreements because of the difficulty in changing them later. This is a lesson to be remembered for a small least developed country eyeing joint exploitation of their mega water resources with a big neighbor. For example, it took 36 years to change some terms of the Itaipu Treaty.

3. Each of the massive projects, Itaipu and Yacyretá, were started with only US\$50 million from each country as equity and the rest as loans. This implies that generally accepted $30 \%$ equity (to be invested by the developer/company) standard in Nepal for hydro projects may be substantially lowered, thus increasing the financial viability of the project.

Jeewan P. Thanju, B.Sc. (Civil), M. Engr. has a background in water resources. He served in the Nepal's Irrigation Dept. for more than 24 years and was Executive Director of Water Resources Division in Water and Energy Commission Secretariat of Govt. of Nepal. He has designed and supervised construction of two diversion dams. He is a Technical Auditor and has experiences in hydropower studies. Currently, he is the Editor-in-Chief of HYDRO Nepal journal and adviser to URJA Nepal (in Nepali language) a magazine on energy issues. Corresponding address:jpthanju@yahoo.com.

Ricardo Canese, M. Engr. (Py), is an engineer who has spent his life dedicated to the issue of Paraguay's Energy resources. At present, he is Technical Itaipu Adviser of the Foreign Affairs of the new Paraguayan Government and MERCOSUR Parlamentair (200813). He has published about 20 researches (books) and some 1,0oo articles (newspapers, and academic press) on Itaipu and Yacyretá hydro electric projects. He was Energy and Mining Subsecretary in 19992000.

Corresponding address: ricardocanese@yahoo.es.

\section{References}

Anonymous, 2011, Economy Statistics > GDP (per capita) (most recent) by country, in Nationmaster.com (encyclopedia), Woolrich NSW, Australia: Rapid Intelligence. URL: www.nationmaster.com/graph/ eco_gdp_percap-economy-gdp-per-capita.

Anonymous, 2011, Itaipu Dam. URL: en.wikipedia.org/ wiki/Itaipu_Dam.

Anonymous, 2011, Yacyretá Dam. URL: en.wikipedia. org/wiki/Yacyretá Dam.

MercoPress, 2009 (27 July), Brazil agrees to treble payment for Paraguay's energy from Itaipu, Motevideo: MercoPress (South Atlantic News Agency). URL: en.mercopress.com/2009/07/27/brazil-agrees-totreble-payment-for-paraguays-energy-from-itaipu.

Nickson, R.A., 2010, Revising the past: The Paraguayan energy sector in perspective, pp.29-37 in T. Harmer and G. Burton, eds., Powering Up: Latin America's Energy Challenges, London: LSE Ideas Latin America International Affairs Programme, London School of Economics. URL: www.download.bham.ac.uk/idd/ pdfs/paraguayan-energy-sector.pdf.

Pun, S.B., 2010, Pancheshwar multipurpose Project: Nepal's portion of power, HYDRO Nepal: Journal of Water, Energy and Environment (Kathmandu), 6:2-8.

Stratfor (Estados Unidos), 2009 (May 27), Paraguay, Brazil-At an Impasse Over Itaipu Output, Austin, Texas: Stratfor Global Intelligence.

\section{Endnotes}

1. The Itaipu financial and the electricity supply conditions will be analyzed in 2023, according the debt and the power that each country will contract in that year (Annex C, Article VI). There is no obligation to review the main treaty articles, for instance that Paraguay must sell to Brazil all its energy that does not use. According to the July 25, 2009 accord between Brazil and Paraguay, it will be possible from 2023 to sell together energy to third countries. Paraguay claims the right to do it now, alone, and not together with Brazil.

2. \& 3. According to the Itaipu Treaty, the tariff must be equal to the service cost. The service cost, because of the huge debt, it is now at US $\$ 22.6 / \mathrm{kW}$-month. If Itaipu generates $90,000 \mathrm{GWh} /$ year, the average cost it is about $\$ 38 / \mathrm{MWh}$. When Brazil buys its own energy, it pays only $\$ 38 /$ MWh. When it buys the Paraguayan electricity, it must pay the service cost ( $\$ 38 / \mathrm{MWh})$ plus the compensation ( $\$ 2.81 / \mathrm{MWh})$. Then, the tariff for ELETROBRAS it is about $\$ 40.81 / \mathrm{MWh}$, in the case of the Paraguayan Itaipu energy. The compensation is really the electricity exportation net profit (what Paraguay receives after it has been paid all the costs). 